\title{
DECOLONISING LEGAL EDUCATION IN SOUTH AFRICA: A REVIEW OF AFRICAN INDIGENOUS LAW IN THE CURRICULUM
}

\author{
by Joshua Mawere*
}

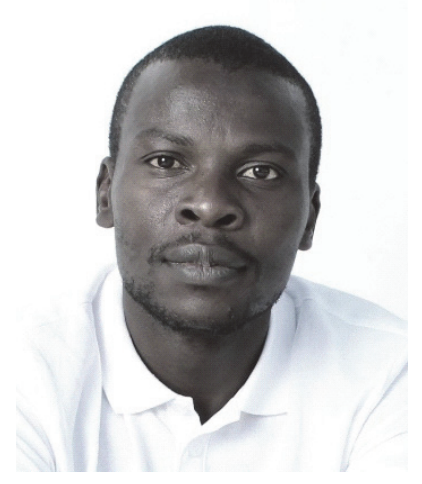

\section{Abstract}

The student demonstrations in universities, which began in 2015, demanded the decolonisation of higher education. The demands included free education and a decolonised curriculum. In the field of law, the demand is anchored in changing the law curriculum. The central issues accompanying the demand are the status of indigenous law, legal history, concept of law, how law is taught and the role of law in African societies. The article examines the necessity of decolonising legal education in relation to the curriculum and the teaching of law in South African universities. The article adopts a doctrinal approach to assess the need to transform the curriculum. The article is grounded in the theory of Afrocentricity in a bid to revive the African paradigm and to examine legal epistemology in post-colonial South Africa. The argument developed in this article is that the legal education system has not significantly been decolonised since 1994. Arguably, the education system is founded on European theories and systems, hence difficult or impossible for the students in Africa to relate. This article recommends that a new curriculum that reflect laws, principles and customs of the African people must be introduced in the South African

LLM, University of Venda, Corporate Internal Legal Advisor at Superior Quality Engineering and Technologies 8 (Pty) Ltd. joshuamawerem@gmail.com. I would like to acknowledge Prof Ademola Jegede and Annette Lansink for their invaluable contribution to this article. 
legal education. Institutions are also encouraged to take positive steps to decolonise legal education and end eurocentrism. ${ }^{1}$

Key Concepts: Living indigenous law, Decolonisation of legal education, Legal education.

\section{Introduction}

In recent times, there has been an intense debate on the decolonisation of legal education in South Africa. This article seeks to contribute to this discourse by examining the African response to the decolonisation of the law curriculum. The article uses the theory of Afrocentricity in a bid to revive the African paradigm and to examine legal epistemology in post-colonial South Africa. This theory is not easily susceptible to definition and various scholars have attempted to capture its essence. Asante defines Afrocentricity as a 'mode of thought and action in which the centrality of African interests, values, and perspectives predominate'. ${ }^{2}$ The American essayist and culture critic Early et al defines Afrocentricity as 'an intellectual movement, a political view, and/or a historical evolution that stresses the culture and achievements of Africans.' 3 According to the Nigerian author Chukwuokolo, Afrocentricity means 'African centeredness', bestowing Africans pride as instigators of civilisation. ${ }^{4}$

Afrocentricity is not without criticism. While Mbembe advocates for decolonisation of knowledge and the university, he is critical of Afrocentricity. He contends that Afrocentricity is the transfer into native hands of those unfair advantages which were a legacy of the colonial past, and that the discourse of Africanisation was itself ideological and retrogressive as it can lead to xenophobia and chauvinism. ${ }^{5}$ In my view, the argument is misdirected. What is correct is the viewpoint of Asante that Afrocentricity is only one of several cultural perspectives from which multiculturalism in education is derived. In his further view, since Afrocentricity is not the opposite of Eurocentricity, it does not seek to replace Eurocentricity. Rather it is based on the harmonious coexistence of an endless variety of cultures. ${ }^{6}$ Varma also argues that 'the aim of Afrocentricity is not

1 S Heleta 'Decolonisation of higher education: Dismantling epistemic violence and Eurocentrism in South Africa' (2016) 1 Transformation in Higher Education 5.

2 MK Asante Afrocentricity: The theory of social change (2001) 2; Asante is constantly acknowledged as the originator of the concept 'Afrocentricity' and the one who introduced it as an academic debate.

3 G Early et al 'Symposium: Historical roots of Afrocentrism' (1994) 7 Academic Questions 44-54.

4 JC Chukwuokolo 'Afrocentrism or Eurocentrism: The dilemma of African development' (2009) 6 OGIRISI: A New Journal of African Studies 32.

5 AJ Mbembe 'Decolonizing the university: New directions' (2016) 15 Arts and Humanities in Higher Education 33-34.

6 Asante (n 2 above) 138. 
reselecting the bars to form new divides'. ${ }^{7}$ Chukwuokolo argues that Afrocentrism, which means African centeredness, does not violently confront any person or people, but is a resolute attempt to put the records right. It is about situating African people in the context of their historical framework to assert their footprints in world history. ${ }^{8}$

According to Mbembe, the legal education system in South Africa keeps masquerading as replicas of the universities in the Western world but fails to demonstrate the same productivity as the original institutions they continue to mimic. ${ }^{9}$ The syllabi were designed to meet the needs and interest of colonialism and apartheid. Hence, the then Minister of Education, Prof Bengu observed that 'the higher education system must be transformed to redress past inequalities, to serve a new social order, to meet pressing national needs and to respond to new realities and opportunities.'10 In the same vein, Yesufu quoted in 'Internationalisation and African Intellectual Metissage: Capacity-Enhancement Through Higher Education in Africa' by Hagenmeier et al had argued that:

$\ldots$ the emergent African university must ... be much more than an institution for teaching, research and dissemination of higher learning. It must be accountable to, and serve, the vast majority of the African people who live in rural areas. ${ }^{11}$

For these reasons, it is axiomatic that the law curriculum and education structure must undergo a process of decolonisation both of knowledge, content and of the university as an institution. There is need for a paradigm shift in the law curriculum in order to respond to the peculiar and specific needs of the African indigenous people. The legal institutions must not only be seen to be built and sited in Africa, but must be of Africa, drawing inspiration from Africa and eloquently devoted to her ideals and ambitions. ${ }^{12}$

\section{The colonial education system}

The crux of colonialism is centred on destroying all knowledge contrary to Eurocentric ideologies, opinions and views. Lebakeng argues that 'during colonial wars of conquest the Western colonialist instituted epistemicide (a destruction of African knowledge and

7 P Varma 'Decolonising universities conference', University of Cincinnati https: // www. youtube.com/watch=KVfevgW608c (accessed on 20 April 2019).

$8 \quad$ Chukwuokolo (n 4 above) 33.

9 Mbembe (n 5 above) 39.

10 South African White Paper on Higher Education: Programme for the Transformation of Higher Education (1997) 3.

11 CCA Hagenmeier et al 'Internationalisation and African intellectual metissage: Capacity-enhancement through higher education in Africa' (2017) 31(1) South African Journal of Higher Education 84.

12 As above. 
systems) and imposed a Western colonial epistemology'.13 Colonialists believed that Africans were uncivilised and primitive and that as superior human beings, colonialists had the mandate to civilise the uncivilised people of Africa. ${ }^{14}$ Colonialists argue Africa was both terra incognito and terra nullius (unknown continent). According to Modiri:

[C]olonial domination in South Africa both produced and then worked to maintain and institutionalise a political ontology that positioned white people at the zenith of all definitions of humanity (civilisation, reason, morality) while simultaneously placing Black people at the nadir of the social hierarchy and binding them into perpetual inferiority and powerlessness. ${ }^{15}$

It is thus not surprising that the effect of the colonial system was to model the colonised to think and reason like the coloniser. ${ }^{16}$ Education was one of the mechanisms that colonialists allegedly adopted to civilise Africans. ${ }^{17}$ Education relates to the process of imparting knowledge, judgment and skills. Legal education therefore communicates to the process of imparting legal knowledge and skills to law students in universities. Legal education in Africa is predicated on Eurocentric methodologies, its main sources being Roman-Dutch law and English law. ${ }^{18}$ It is on this basis that it is criticised for being Eurocentric, persistently advancing Western dominance, and at the same time being full of stereotypes, biases and patronising opinions about Africans. ${ }^{19}$

Mamdani, the Ugandan intellectual, contends that 'colonial education pretends that knowledge is not always partial and passes the intellectual fraction off as the whole' .20 Mbembe also argues that colonial education falsifies a variety of phenomena, including among others, land and knowledge. ${ }^{21}$ According to Kanengoni, it hinders access to knowledge and inhibits unrestricted inquiry and search for

13 T Lebakeng 'Towards a relevant higher education epistemology' in S Seepe (ed) Towards an African identity of higher education (2004) 109-119.

$14 \mathrm{C}$ Himonga \& $\mathrm{F}$ Diallo 'Decolonisation and teaching law in Africa with special reference to living customary law' (2017) 20 Potchefstroom Electronic Law Journal 1.

15 JM Modiri 'Conquest and constitutionalism: first thoughts on an alternative jurisprudence' (2018) 34 South African Journal on Human Rights 4.

$16 \mathrm{R}$ Grosfoguel 'The epistemic decolonial turn: Beyond political-economy paradigms' (2007) 21 Cultural Studies 211-223.

17 I Léglise \& B Migge 'Language and colonialism. Applied linguistics in the context of creole communities' (2008) https://halshs.archives-ouvertes.fr/halshs-0029 2388/document (accessed 6 January 2020).

18 Himonga \& Diallo (n 14 above) 5.

19 Lebakeng (n 13 above) 112.

20 M Mamdani 'Between the public intellectual and the scholar: Decolonization and some post- independence initiatives in African higher education' (2016) 17 InterAsia Cultural Studies 68-83.

21 Mbembe (n 4 above) 29. 
truth in scholarship. ${ }^{22}$ Kanengoni's view is that a legal curriculum based on imported legal ideas, principles and theories assures a people of being 'controlled and ran'. It produces African students who are only good at translating and interpreting Eurocentric ideologies, with nothing to offer the community of legal scholars. ${ }^{23}$ The primary objective of legal scholarship in Africa must be to provide and teach insights that are relevant and accessible to Africans but rare to other cosmologies. ${ }^{24}$ It is for these reasons, that there has been an outcry to decolonise legal education. The general uproar by most African students is advocating for a decolonised curriculum to guarantee a departure from the history of colonialism.

Thaman writes that 'decolonising formal education involves accepting indigenous and alternative ways of seeing the world' ${ }^{25}$ In this context, the concept of decolonising legal education leads to Africanising legal education. ${ }^{26}$ Placing the Africans' interest at the centre of education is important. In the words of the Kenyan writer Ngũgĩ wa Thiong'o:

Education is a means of knowledge about ourselves .... After we have examined ourselves, we radiate outwards and discover peoples and worlds around us. With Africa at the centre of things, not existing as an appendix or a satellite of other countries and literatures, things must be seen from the African perspective. All other things are to be considered in their relevance to our situation and their contribution towards understanding ourselves. In suggesting this we are not rejecting other streams, especially the Western stream. We are only clearly mapping out the directions and perspectives the study of culture and literature will inevitably take in an African university. ${ }^{27}$

Other authors have reinforced the position of Ngũgĩ wa Thiong'o. Nkoane posits that such an education should emancipate Africa to produce the knowledge that can help solve their living problems. ${ }^{28}$ According to Himonga and Diallo, decolonisation is 'a move from a hegemonic or Eurocentric conception of law connected to legal cultures historically rooted in colonialism in Africa to more inclusive legal cultures'. ${ }^{29}$ Decolonising legal education is thus about re-

22 D Kanengoni 'Transformative Education: The Education We Need by 2030' (2016) 7 BUWA 1-7.

23 Kanengoni (n 22 above) 14.

$24 \mathrm{~N}$ Mahao 'O se re ho morwa 'morwa towe'! African jurisprudence exhumed' (2010) 43 Comparative and International Law Journal of Southern Africa 317-336.

25 KH Thaman 'Decolonizing pacific studies: Indigenous perspectives, knowledge and wisdom in higher education' (2003) 15 The Contemporary Pacific 1-17.

26 Decolonisation of the curriculum is about Africans seeing themselves "clearly in relationship with [themselves] and other selves in the universe'. This is consistent with Africanisation that requires the curriculum to have more local content. This implies that the content must be 'African focused content'.

27 Ngũgĩ wa Thiong'o Decolonising the mind: The politics of language in African literature (1986) 87.

28 MN Nkoane 'The Africanisation of the university in Africa' (2006) 13 Alternation 49-69.

29 Himonga \& Diallo (n 14 above) 5. 
emerging subdued indigenous knowledge and re-entering the knowledge project of all legal institutions from an African point of view. To achieve this objective, Himonga and Diallo argue in favour of introducing 'living indigenous law' in the law curriculum.

\section{State of legal education in South Africa}

This section elaborates on the state of legal education in South Africa. The section is categorised into two arguments. The first argument is that the law in South Africa and the legal curriculum remains under colonial and apartheid subjectivity twenty-five years after independence. South Africa remains under oppression as it is defined by unrepressed asymmetries of power and continues to display features of stratification, exploitation, violence, marginalisation, powerlessness and cultural dominance. In fact, South African law, mainly the Constitution is criticised for being a neo-apartheid charter that facades continuing domination. ${ }^{30}$ Modiri states that:

... the Constitution is figured not only as a supreme law but also a supreme rationality. Not only is it a formal law-text but it is also a particularly hegemonic public grammar, political imaginary and a form of historical and social consciousness. It embeds particular cultural and ideological values into its fold and as such works to consolidate and preserve particular arrangements and relations of power and knowledge. Understood in this way, the Constitution must be implicated in the continuation of colonial-apartheid power relations, value systems and subjectivities. How else could we explain why the advent of constitutional democracy in South Africa has left white supremacy and coloniality largely undisturbed? What interests and powers does the Constitution secure and leave untouched, and what realities and demands does it silence, minimise or erase? ${ }^{31}$

The argument is that the Constitution, "deifies a "teleological" kind of "whiteness" as aspiration, if as an ordinary black South African you need to be treated as human'. ${ }^{32}$ It is absurd that we are in South Africa, an African country, but law is only taught in Afrikaans and English. An African child is compelled to appreciate and understand either of the two languages before he or she can dream to study law. There is a need to strike a balance when it comes to the teaching of law. What is wrong in teaching indigenous law in IsiZulu at an institution situated in KwaZulu Natal or teaching in Tshivenda at a

30 F Fanon The wretched of the earth (2004) 97-144 who states that the term 'neocolonialism' was, after all, coined precisely to capture the dilemma of postcolonial African states that, after gaining national independence, simply replicated the ways of the 'former' colonial power and plunged the formally liberated population into a deepening phase of unfreedom and stagnation.

31 JM Modiri 'Towards a (post-)apartheid critical race jurisprudence: "divining our racial themes"' (2012) 27 South African Public Law 231-258.

32 K B Motshabi 'Decolonising the University: A law perspective' (2018) 40(1) Strategic Review for Southern Africa 104. 
university situated in Thohoyandou? Madlingozi argues that 'the Constitution fails to dislodge white supremacy and constitutes a post1994 conquest'.33 Modiri cements this argument by calling for elimination of the structures, practices and relations of coloniality and white supremacy in the educational system. ${ }^{34}$

Following this discussion, the general argument is that colonialists through the Constitution succeeded in relinquishing the crown but keeping the jewels. ${ }^{35}$ This is because the settlement leading to the drafting of the Constitution was driven more by the need to realise stability and peace rather than justice, hence it inclined more towards protecting white people's unfairly acquired interest, translating them into constitutional rights. In this sense, the Constitution cannot rationally be categorised as 'non-racial', when it keenly protects interests secured through racial oppression. The conundrum is that the Constitution, in terms of the Bill of Rights, is the supreme law of the land. All laws inconsistent with the Constitution are null and void. Thus, it follows that the legal curriculum develops from the same Constitution. If that is the case, then it is reasonably possible to argue that even the curriculum itself is tainted with colonial supremacy.

Secondly, there exists uneasiness at the failure of the South African government and universities to accord appropriate status to indigenous law and African values. There has been an attempt to include indigenous law in the legal system and the curriculum at large. However, progress in this regard has been sporadic. The decry is predicated against 'starting with existing schools of jurisprudence developed elsewhere for different conditions and requirements' and 'imposing them on local conditions'. ${ }^{36}$ The general view is that there is need for academic change. As Maldonado-Torres rightly argues, in addition to a critical interrogation and revision of received theories and ideas, new concepts must be built by African intellectuals. ${ }^{37}$

South Africa over-relies on Western legal scholarship, most probably this is due to colonial history as well as the huge influence of colonialism on colonial universities. ${ }^{38}$ Lenta argues that the 'Western theories we use are inadequate to local problems and the

33 T Madlingozi 'Social justice in a time of neo-apartheid constitutionalism: Critiquing the anti-black economy of recognition, incorporation and distribution' (2017) 28(1) Stellenbosch Law Review 123-147.

34 Modiri (n 31 above) 237.

35 A Mazrui 'Pro-democracy uprisings in Africa's experience: from Sharpeville to Benghazi' (2011) Africa Day Lecture 7.

36 R Odgaard \& BA Weis 'The interplay between collective rights and obligations and individual rights' (1998) 10 European Journal of Development Research 105-116.

37 N Maldonado-Torres 'The crisis of the university in the context of neo-apartheid: A view from ethnic studies' (2012) 10 Human Architecture: Journal of the Sociology of Self Knowledge 91-100.

38 Mamdani (n 20 above) 71. 
European lens does not perceive our complexity'.39 The Western theories specialise in producing future lawyers, magistrates and judges who are embedded in positivism and centralism. Legal positivism and centralism remain the leading theoretical framework within which law is taught in most law schools in South Africa. It finds its roots in Roman-Dutch and English law. Legal positivism and centralism are often criticised for producing lawyers and judges who can engage with Western legal systems and cultures and not with African legal systems, in particular, oral legal traditions. ${ }^{40}$ Legal positivism is embedded in formalism. Formalism separates legal rules and morality or political philosophy. ${ }^{41}$ The theory requires litigants and judges to apply the law or rules to the facts deductively. This is contrary to indigenous law. Rules of 'living' indigenous law cannot be abstracted from their social contexts. ${ }^{42}$ Indigenous law is entrenched in the social actualities within which people live their lives. Indigenous law is not embedded in aspects of certainty and predictability-factors which form the basis of Western legal cultures. ${ }^{43}$ These theories produce lawyers and judges who lack appreciation of indigenous law and regard it as irrelevant.

For example, in Bhe $v$ Magistrate, Khayelitsha, the court showed willingness to step beyond the dominant influence of positivism and centralism. ${ }^{44}$ However, despite the willingness, the judges found themselves retreating to their predominantly Western law and theoretical training when applying customary law. They retraced their footsteps to positivism. Evidently, the court moved away from moral considerations and customary practices and was guided by the positivist theory that concludes that laws and their operation derive validity from the fact of having been enacted by authority or of deriving logically from existing decisions, rather than from any moral considerations. The court recognised the concept of 'living' indigenous law, including its flexibility and the fact that it is less rulebound. However, most judges decided to focus on the values of certainty and uniformity. They retraced their steps towards positivism and centralism. The discussion confirms that despite the judges' willingness to uphold and develop indigenous law, their education and training under positivism and centralism influenced their decision.

39 P Lenta 'Just gaming? The case for postmodernism in South African legal theory' (2001) 17 South African Journal on Human Rights 173-209.

40 Bhe and others $v$ Khayelitsha Magistrate and others 20051 (SA) 580 (CC) (hereinafter referred to as 'Bhe $v$ Magistrate'); Shibi $v$ Sithole 20051 (SA) 580 (CC); South African Human Rights Commission $v$ President of the Republic of South Africa 2005 (1) SA 580 (CC) paras 110-112.

41 B Leiter 'Legal formalism and legal realism: What is the issue?' (2010) 2 Cambridge University Press 111.

42 Living customary law is the law that governs the legal relations of people who are subject to a given system of customary law in their day-to-day life.

43 TW Bennett Human rights and African customary law under the South African Constitution (1999) 46.

44 Bhe $v$ Magistrate (n 40 above) paras 110-112. 
The ghost of training judges and lawyers in legal centralism and positivism continues to follow them when applying indigenous law. ${ }^{45}$

\section{The way forward}

Arguably, three fundamentals are indispensable for decolonising legal education. A discussion of these follows:

\subsection{Centring indigenous law in the curriculum}

Legislation defines indigenous law as 'the customs and usages traditionally observed among the indigenous African peoples of South Africa which form part of the culture of those people' ${ }^{46}$ Culture is dynamic, hence the mentioning of the word 'culture' in the definition is suggestive of the dynamic nature of 'living' indigenous law. 'Living' indigenous law according to Hund, 'represents the practices or customs observed and invested with binding authority by the people whose customary law is under consideration'. ${ }^{47}$ The beauty of indigenous law is that, its evolution and progression is fashioned within changing African political, social and economic contexts. It is unwritten and passed down orally from generation to generation. The oral nature of indigenous law makes it easily adjusted to meet the different needs of justice in a decolonised context. ${ }^{48}$

Others, as discussed earlier, may argue that indigenous law already forms part of South African law and legal education system. While this is correct, this article argues that the inclusion of indigenous law - 'old' indigenous law in the current education and legal system is flawed and insufficient. The 'old' indigenous law consists of codifications of indigenous law and these include legislation such as the Black Administration Act, ${ }^{49}$ the Natal Code of Zulu Law, ${ }^{50}$ case law, textbooks and so on. The 'old' indigenous law as explained above, bears colonial and apartheid marks. This argument is predicated on the view that 'old' indigenous law is distorted because it was designed to advance colonial and apartheid

45 C Himonga 'The Constitutional Court of Justice Moseneke and the decolonisation of law in South Africa: Revisiting the relationship between indigenous law and common law - Justice Moseneke, transformation, equality and indigeneity' (2017) 1 Acta Juridica 101.

46 Recognition of Customary Marriages Act 120 of 1998 section 1.

$47 \mathrm{~J}$ Hund 'Customary law is what people say it is - HLA Hart's contribution to legal anthropology’ (1998) Archiv für Rechts-und Sozialphilosophie 420-429.

48 Odgaard \& Weis (n 36) 105.

49 Black Administration Act 38 of 1927. This Act regulated Black South Africans during the apartheid era. Several aspects of the Act have been repealed, except for a few provisions that remain in existence.

50 Proclamation No. R. 151, Natal Code of Zulu Law, 3 September 1987. 
state interest. ${ }^{51}$ Therefore, its inclusion in legal education is propagating and preserving colonial legacy. This contrasts with the ideology of decolonisation. For this reason, 'old' indigenous law must not form the core part of the legal curriculum. To the contrary, I suggest the inclusion of 'living' indigenous law in the legal curriculum. Restructuring legal education should be considered as a matter of exigency of historic and fundamental justice.

'Living' indigenous law should inform the entire law curriculum. There is need for a mind shift towards a greater incorporation of indigenous knowledge. The inclusion of indigenous law must not be restricted to merely one subject that stands alone like the status quo in most South African universities. Rather, indigenous knowledge, values, customs and practices should inform the entire law curriculum. African knowledge, worldview, experience, norms and values should be at the centre of scholarship and knowledge seeking. Kwame Nkrumah argues that 'we must in the development of our universities bear in mind that once it has been planted in the African soil it must take root amidst African traditions and cultures'. ${ }^{52}$ In the same vein, Mamdani argues that the university must adapt its scholarship to the social structure and the cultural environment of Africa by producing knowledge that takes the African condition and the African identity as its central problem. ${ }^{53}$ An African university must be the custodian of African knowledge. This is not going to be an easy task because there is need for much research on African law and values and there will be contestation. To be realistic, this will be a gradual process considering that we now live in a fast-moving global world with masses of changes to systems.

'Living' indigenous law is not without criticism. It is criticised for being unsystematic, fragile and inconsistent. The South African writer Bennet, argues that rules of an oral regime are porous and malleable. Because they have no clear definition, it is difficult to differentiate one rule from another, and, in consequence, to classify rules per type. If rules cannot be classified, they cannot be arranged into a system, and without the discipline of a system, rules may overlap and contradict one another. In fact, strictly speaking, the oral versions of customary law should not be called systems at all. They are probably better described as repertoires, from which the discerning judge may select whichever rule best suits the needs of the case. ${ }^{54}$ The statement clearly demonstrates that indigenous law methodology does not place emphasis on systemisation, thus it does not embody a rigid framework unlike Eurocentric laws. It is the writer's view, as

51 M Chanock Law, custom and social order. The colonial experience in Malawi and Zambia (1985) 219.

52 Quoted in SP Seepe Towards an African identity of higher education (2004) 13.

53 Mamdani (n 20 above) 81.

54 Bennett (n 43) 52. 
depicted from the above-mentioned arguments, that 'living' indigenous law is flexible and adaptable. Its distinctive nature and originality are a positive development in decolonising law. Its uniqueness and originality as an evolving source of law compels its inclusion in a decolonised system of legal education.

Africa has a lot to offer towards legal scholarship apart from memorising and interpreting European theories. Legal education requires a sincere 'totality' of universal knowledge. ${ }^{55}$ This permits a true search for truth. Africans deserve to be given an opportunity to contribute immensely towards legal scholarship. Africans must be able to claim space and authority in the field of knowledge production and dissemination. However, the call to decolonise legal education does not imply jettisoning every Western concept. The idea is 'not to debunk British colonial and Afrikaner Christian nationalism, but to identify that which is authoritarian, patriarchal, and Eurocentric from that which is emancipatory and liberatory'. ${ }^{56}$

The existing curriculum brought with it a lot of positives. It has been argued, for instance, that the call to decolonise the University of Cape Town is not to return it to the pristine condition prior to the arrival of the settlers. ${ }^{57}$ The idea is to critically interrogate the knowledge system of that era and elicit what is helpful in addressing contemporary challenges. ${ }^{58}$ The above-mentioned statements caution against adopting a romanticised and rhetoric concept of decolonisation. It is argued that, South Africa must avoid advancing the unconditional and uncritical indigenisation of law, that permits an anti-colonial discourse that is stuck within the same colonial epistemology. The statement also satirically proposes that before colonisation, Africa had its own challenges and the existing call for decolonisation does not outright make Africa all glorious and unblemished.

To conclude, 'living' indigenous law must be taught in all law schools to equip law students to comprehend indigenous law within the constitutional framework of South Africa. This is essential to equip students to have lenses that observe indigenous law and not from the perspective of foreign legal systems. ${ }^{59}$

$55 \mathrm{H}$ Hudson 'Decolonising gender and peacebuilding: Feminist frontiers and border thinking in Africa' (2016) 4 Peacebuilding 192-209.

56 Seepe (n 52) 15.

57 M Price \& R Ally UCT 2015 Year in Review 23.

58 As above.

59 Alexkor Ltd $v$ Richtersveld Community 2004 SA 460 (CC) para 51 where the court held that "while in the past indigenous law was seen through the common law lens, it must now be an integral part of our law. Like all law it depends for its ultimate force and validity on the Constitution. Its validity must now be determined by reference not to common law, but to the Constitution'. 


\subsection{Academics that Relate to Indigenous Knowledge Systems}

Ngũgĩ asks the question: Who should be interpreting that material to them, an African or non-African? If African, what kind of African? One who has internalised the colonial world outlook or one attempting to break free from the inherited slave consciousness. ${ }^{60}$ It is important when decolonising legal education to ensure that academics must understand and conceptualise indigenous knowledge systems. While this sounds farfetched, it remains a valid argument. Law schools require academics who relate to African culture, problems, languages and way of life. This proposition is not advocating for an exclusion of non-African academics or Africans who have internalised the colonial world outlook. They remain relevant and necessary. However, when it comes to accessing indigenous knowledge and decolonising the content of legal education, institutions require academics who are 'attempting to break free from the inherited slave consciousness' as stated by Ngũgĩ. ${ }^{61}$ An academic who appreciates and understands indigenous knowledge systems is most suitable to teach indigenous law modules as compared to an academic who understands indigenous law only from a Eurocentric view or understanding. The proposition promotes collaborative research, where both the academics and students apply personal lived experiences.

\subsection{Adopting an Interdisciplinary and Multicultural Approach}

The adoption of an interdisciplinary approach in legal education is vital for the decolonisation of legal education in South Africa. The National Science Foundation defined an interdisciplinary approach as:

$[A] n$ approach that integrates information, data, techniques, tools, perspectives, concepts, and/or theories from two or more disciplines or bodies of specialised knowledge to advance fundamental understanding or to solve problems whose solutions are beyond the scope of a single discipline. ${ }^{62}$

The article argues that the adoption of an interdisciplinary approach offers a podium of understanding law in all its manifestations. There is a need to fuse legal science with other disciplines. It is the writer's view, that law is meant to address problems, however most of these problems lie beyond a single discipline and culture. This confirms the need to integrate and understand legal knowledge from different disciplines. The article advocates for an interdisciplinary approach that allows Eurocentric theories, views and ideologies to work

60 Wa Thiong'o (n 27 above) 88.

61 As above.

62 National Science Foundation 'What is interdisciplinary research?' http://nsf.gov/ od/oia/additional_resources/interdisciplinary_research/definition's (accessed 17 November 2019). 
together with Afrocentric theories, views and ideologies. Our law must not be subsumed or explained from the viewpoint of Eurocentric theories only. This kills the ability to search for the truth in legal scholarship. Mamdani posits that:

Excellence has to be contextualised and knowledge made relevant. Shed this mimicry of the West that continues to parade as universal excellence and take on the challenge to produce knowledge that takes the African condition as its central problem. The African condition is historical and not biological. ${ }^{63}$

Data must be collected from all disciplines and cultures. This ensures checks and balances on the theories produced. The ordinary perception of an interdisciplinary approach relates to different fields, for example, sociology and anthropology. However, this article aims to define an interdisciplinary approach from the context of fusing Eurocentric myths and theories with African theories and knowledge systems. The writer recommends a departure from a law syllabus that is individually aligned to European views and rather argues for a decolonised syllabus that represents both European and African views and knowledge. The writer recommends a teaching of law that is responsive to social and legal plurality. Legal education cannot continue to be unresponsive to colonial history. Legal education must endeavour to decolonise law beyond vernacularisation. Law must be developed based on peoples living experiences and not solely on borrowed theories.

\section{Conclusion}

In summary, the writer contends that legal education should be decolonised and 'Africanised'. The writer also contends that unless the law curriculum and the teaching of law is redesigned to move away from the theoretical paradigm within which it is taught, the plan of decolonising law in South Africa will fail and the education system will remain colonised.

63 M Mamdani 'Citizen and Subject: Contemporary Africa and the Legacy of Late Colonialism' (1997) 1(2) African Sociological Review 96-144. 